\title{
Affinity Binding Macroporous Monolithic Cryogel as a Matrix for Extracorporeal Apheresis Medical Devices
}

\author{
Wuraola Akande ${ }^{1,2, ~ *, ~ L y u b a ~ M i k h a l o v s k a ~}{ }^{1}$, Stuart James ${ }^{1}$, Sergey Mikhalovsky ${ }^{1,3}$ \\ ${ }^{1}$ Biomaterials and Medical Devices Research Group, School of Pharmacy and Biomolecular Sciences, Huxley Building, University of \\ Brighton, Brighton, UK \\ ${ }^{2}$ Department of Clinical Pharmacy and Pharmacy Administration, Faculty of Pharmacy, University of Ibadan, Ibadan, Nigeria \\ ${ }^{3}$ School of Engineering, Nazarbayev University, Astana, Kazakhstan
}

Email address:

wa20@brighton.ac.uk (W. Akande),wuradol@gmail.com (W. Akande), L.Mikhalovska@brighton.ac.uk (L. Mikhalovska), S.L.James@brighton.ac.uk (S. James), s.mikhalovsky@brighton.ac.uk (S. Mikhalovsky), smikhalovsky@nu.edu.kz (S. Mikhalovsky)

\section{To cite this article:}

Wuraola Akande, Lyuba Mikhalovska, Stuart James, Sergey Mikhalovsky. Affinity Binding Macroporous Monolithic Cryogel as a Matrix for Extracorporeal Apheresis Medical Devices. International Journal of Biomedical Materials Research. Vol. 3, No. 5, 2015 , pp. 56-63. doi: 10.11648/j.ijbmr.20150305.11

\begin{abstract}
Cytapheresis is an extracorporeal separation technique widely used in medicine for elimination of specific classes of blood cells from circulating blood. It has been shown recently to have clinical efficacy in various disease states, such as leukaemia, autoimmune disorders, rheumatoid arthritis, renal allograft rejection and sickle-cell anaemia. The current study was undertaken to produce an affinity-binding column, based upon a macroporous monolithic cryogel with a structure of interconnected pores, with pore size and low flow resistance potentially suitable for use in cytapheresis. The affinity column was produced from poly (2-hydroxyethyl methacrylate) PHEMA cryogels synthesized by free radical polymerization at $-12^{\circ} \mathrm{C}$. This study involved assessing haemolytic potential, and functionalisation of polymer matrix with biological ligands. Haemolytic potential of poly (2-hydroxyethyl methacrylate) cryogel was established by measuring free haemoglobin after blood filtration through the column. The anti-human albumin (antibody) was chemically coupled to the epoxy derivatised monolithic cryogels and the binding efficiency of anti-human albumin (antibody) to the cryogel was determined. Our results show that approximately $100 \%$ of Red blood cells passed through the column with no evidence of haemolysis found in blood eluted. It was found that $\sim 82 \%$ of human serum albumin was retained on the monolithic IgG anti-human albumin cryogel matrix. The obtained results suggest that poly (2-hydroxyethyl methacrylate) monolithic cryogel is a non-haemolytic material (haemocompatible matrix) capable of functionalisation with antibody and thus can be an appropriate matrix for use in extracorporeal apheresis system.
\end{abstract}

Keywords: Macroporous Cryogel, Poly (2-Hydroxyethyl Methacrylate), Anti-Human Albumin Antibody, Affinity Cryogel, Ligand Immobilisation, Monolithic Adsorbent, Cell Separation, Haemocompatibility

\section{Introduction}

Cytapheresis is aimed at separation of certain types of cells from blood by either centrifugation or adsorption. It has long been acknowledged that specific removal of pathologically significant cells or formed elements is an attractive perception. Cytapheresis has been shown recently to have clinical efficacy in various disease states, such as leukaemia, autoimmune disorders, rheumatoid arthritis, renal allograft rejection, and sickle-cell anaemia [1-2]. Various physicians have reported the efficacy of cytapheresis in inflammatory bowel disease such as ulcerative colitis and Crohn's disease
[3-8]. The efficacy of LDL-apheresis in homozygous familial hypercholesterolemia and hyperlipidemia has been reported $[9,10]$.

There are mainly three methods of extracorporeal leukocyte removal therapy in use in the clinical field. These are the centrifugal method, filtration and the adsorptive method using fibre or beads. Leukocytapheresis using the leukocyte filter Cellsorba [11] and granulocytapheresis using the Adacolumn [12] have been proved to have reduced leukocyte load in patients with rheumatoid arthritis and inflammatory bowel disease, but still has major limitations of specificity and selectivity [13].

The adsorptive method with beads has been used in LDL- 
apheresis with direct adsorption of lipoprotein and this has been proved to reduce cholesterol level in patients with severe dyslipidaemic and homozygous familial hypercholesterolaemia, but still has limitations due to side effects such as activation of bradykinin $[14,15]$.

Despite its excellent potential, apheresis has not yet received wide clinical applications for a number of reasons. An ideal extracorporeal cell-specific filter device should have combined characteristics, such as low flow resistance, high mechanical and chemical stability, ease of functionalisation, large interconnected pores which can allow unrestricted cell passage, a large material surface area and control of pore size during manufacture [16]. Current filter devices and other apheresis techniques do not meet all, or many of these requirements. It is desirable to have a monolithic column for therapeutic cytapheresis, with continuous on-line cell separation. Use of monolithic columns for chromatographic separations has already been suggested [17] but so far they have not been used for cell separations due to failure in effort to achieve an appropriate pore structure.

These problems can be overcome by employing macroporous monolithic cryogels prepared using cryopolymerisation technology. Cryogels have been shown to have unique properties, most importantly mechanical, chemical and osmotic stability [18], and interconnected macro or supermacropores capable of allowing passage and separation of whole blood cells in a chromatographic regime $[19,20]$. They have also shown shape memory as they can be repeatedly dried and re-swollen in the solvent acquiring the same shape in which they were synthesised [21, 22].

The problem of the non-selective nature of current filter devices and apheresis technique has been addressed in the use of monolithic cryogel for chromatographic separation by the functionalisation of the filter support and attachment of a biological ligand, such as an antibody against target antigen or protein A (an avid ligand for IgG antibody). A recognisable application has been the use of anti-CD4 antibody to remove CD4+ T-lymphocytes [23] or the more widely applicable functionalisation of filter support with protein A to capture antibody-coated cells [24]. The removal of anthrax toxin protective antigen with supermacroporous cryogel adsorbents with immobilized Protein A has been reported recently [25]. This allows a more targeted means of cell isolation, and provides a flexible technological platform that could be applied to a wide range of diseases in clinical applications.

Overall, the technology looks promising and one hopes to develop cryogel bio-specific filter device to be used in extracorporeal medical devices that will be available commercially. This however, provides the possibility that cryogels can be explored for clinical applications requiring haemocompatibility.

Multiple factors can induce haemolysis, such as shear stress, RBC interaction with leachable, chemicals and electrical forces [26]. The most common method to determine the haemocompatibility properties of biomaterials used for blood filter is haemolysis testing. The release of intracellular haemoglobin (haemolysis) can be caused by Red blood cells (RBC) interaction with biomaterials. The haemolysis test has been used for decades to identify the biocompatibility properties of biomaterials [27-30].

The objective of this study is to help provide understanding of the haemolytic potential of poly (2hydroxyethyl methacrylate), PHEMA monolithic cryogel, and further confirm that the availability of binding structure such as antibodies can recognize the surface of the proteins or cells aggregates, thus a general binding and separation system can be established. Considering the fact that the development of improved haemocompatible biomaterials is one of the most important challenges in material science, this paper demonstrated for the first time that PHEMA monolithic cryogel is a non-haemolytic material by passing whole blood through the column by mean of evaluating the free haemoglobin, and amount of red blood cells eluted with the use of Sysmex cell counter and Blakney and Dinewoodie (1975) method. The in-vitro studies on the haemocompatibility of the material produced in this paper reported that $\sim 100 \%\left(4.77 \times 10^{6}\right.$ cells $\left./ \mu \mathrm{L}\right)$ of Red blood cells was eluted after passing whole blood through the monolithic cryogel column and that no haemolysis was observed. According to the international organization for standardization (ISO) developed guidance on testing medical materials that have contact with circulating blood (ISO 10933-4), a haemocompatible material must not interact with any blood components.

There is no reported study of immobilisation of antihuman albumin (antibody) onto a monolithic cryogel via covalent immobilisation with extended linker groups. In this paper, we report for the first time the covalent immobilisation of anti-human albumin on macroporous cryogel columns having epoxy functionalities, synthesised by cryogelation. Affinity binding of human albumin onto coupled anti-human albumin on the surface of the cryogel matrix further confirms that if the binding structure in the form of antibodies is available that recognises the surface of the proteins or cells aggregates, a general binding and separation system can be established for antibody binding cryogel, affinity matrices. These results provide support for the use of macroporous monolithic cryogel in an extracorporeal apheresis medical device.

\section{Materials and Methods}

\subsection{Materials}

2-hydroxyethyl methacrylate, (HEMA 98\%, stabilised), allyl glycidyl ether (AGE 99\%), and N, N'-methylenebisacrylamide, (MBAAm 96\%) were purchased from Acros Organics UK. N, N, N', N'-tetramethylethylenediamine electrophoresis grade (TEMED 97\% Fisher Bio reagents) and ammonium persulfate (APS) were purchased from Fisher Scientific UK. Fresh blood from healthy donor, 3.8\% sodium citrate vacutainer from BD vacutainer Systems, (Franklin Lakes, NY, USA), bicinchoninic acid (BCA) protein assay 
reagent, copper (II) sulphate solution, anti-human albumin IgG 034K4816 (anti-HSA IgG) from sheep serum and human serum albumin (HSA) were purchased from Sigma (St Louis USA), ethylenediamine from Aldrich, sodium borohydride from Fluka. Buffers prepared from sodium phosphate (monobasic and dibasic) and sodium carbonate (monobasic and dibasic) from Sigma. UV/Vis spectrophotometer from Pharmacia Biotech, Sysmex KX-21N cell counter (Sysmex Co., Mundelein, IL, USA) and SP syringe pump connected to pressure box and pressure monitor system were used.

\subsection{Cryogel Synthesis}

Epoxy containing PHEMA cryogel was produced from monomers of 2-hydroxyethyl methacrylate (HEMA $5.28 \mathrm{~mL}$ ) and allyl glycidyl ether (AGE $1.08 \mathrm{~mL}$ ), N, N'methylenebisacrylamide (MBAAm $1.342 \mathrm{~g}$ ) was used as a cross linker. These were dissolved in $92.2 \mathrm{~mL}$ of deionized water (final concentration of monomers $8 \% \mathrm{w} / \mathrm{v}$ ), monomers ratio to MBAAm 6:1. The resulting solutions were degassed for about 20 minutes by using $\mathrm{N}_{2}$ gas or water pipe vacuum. Free radical polymerization was initiated by $\mathrm{N}, \mathrm{N}, \mathrm{N}, \mathrm{N}-$ tetramethylethylenediamine (TEMED) and ammonium persulphate (APS) pair $(1.2 \mathrm{w} / \mathrm{w} \%$ TEMED and $1.2 \mathrm{w} / \mathrm{w} \%$ APS of the total weight of monomers and MBAAm). The mixture was then cooled under ice bath for about 30 minutes. APS was added to the solution for the onset of reaction. The solution $(4 \mathrm{~mL})$ was aliquoted into glass columns, and frozen at $-12^{\circ} \mathrm{C}$ for 18 hours in a cryobath. The cryogels were allowed to thaw at room temperature while still in the glass columns before being washed with water; the gel matrix was stored at $4{ }^{\circ} \mathrm{C}$ till further use.

\subsection{Blocking of the Epoxy Reactive Group}

The epoxy PHEMA cryogel column was washed with 0.1 $\mathrm{M}$ sodium carbonate buffer, $\mathrm{pH} 9.0$ at flow rate $0.5 \mathrm{~mL} / \mathrm{min}$ for 4 hours. Then $50 \mathrm{~mL} 0.1 \mathrm{M}$ ethanolamine $\mathrm{pH} 9.0$ in $0.1 \mathrm{M}$ sodium carbonate buffer were pumped in a recycling mode for 4 hours. Finally, the column was washed with $50 \mathrm{~mL}$ of $0.1 \mathrm{M}$ sodium carbonate buffer at a flow rate $1 \mathrm{~mL} / \mathrm{min}$ to remove all non-reacted ethanolamine, and then stored at $4^{\circ} \mathrm{C}$ until further use.

\subsection{Blood Collection}

Venous blood was collected by clean venepuncture into vacuum tubes containing anti-coagulant (sodium citrate) and was used within 24 hours. The volunteers four in number, were healthy and had not taken aspirin or non-steroidal antiinflammatory drugs within the last 24 hours. The blood collection was done after approval by the Ethics Committee of University of Brighton (Approval number: PABSREC APPLICATION 0902).

\subsection{Blood Cell Count}

The whole blood was counted with Sysmex KX-21N, an automated multiparameter blood cell counter for in-vitro diagnostic use in clinical laboratories. This system processes approximately 60 samples an hour and displays on the liquid crystal display screen the particle distribution curves of white blood cells (WBC), red blood cells (RBC) and platelets, along with data of 19 parameters. WBC and RBC use direct current detection method. The haemoglobin detector block measures haemoglobin concentration using the non-cyanide haemoglobin analysis method. Non-cyanide haemoglobin analysis method applies the advantages of both cyanmethaemoglobin and oxyhaemoglobin methods. Noncyanide haemoglobin analysis method rapidly converts blood haemoglobin as the oxyhaemoglobin method and contains no poisonous substance, making it suitable for automated method. This method is capable of analysing methaemoglobin, hence it can accurately analyse blood, which contain methaemoglobin.

The cryogel column was washed with approximately 50 $\mathrm{mL}$ of $0.9 \% \mathrm{NaCl}$ solution at a flow rate of $1 \mathrm{~mL} / \mathrm{min}$ with the use of SP 200 syringe pump, then approximately $15 \mathrm{~mL}$ of blood were passed through the pump at a speed of 1 $\mathrm{mL} / \mathrm{min}$, as shown in Fig: 2.1 and the fractions of approximately $1 \mathrm{~mL}$ were collected into an eppendorf tube for $\sim 12$ minutes. The fractions in each tube were then evaluated for the cell numbers.

Red blood cell (RBC) count in blood was performed using a Sysmex cell counter and the initial value was observed before passing blood through the column. The experiment was repeated four different times and Red blood cell count were evaluated from the blood eluted after passage through the cryogel column. Blood was pumped through the column at a flow rate of $1 \mathrm{~mL} / \mathrm{min}$ up until 12 minutes. The first $5 \mathrm{~mL}$ eluted were discharged to make sure any dilution of blood samples with $0.9 \% \mathrm{NaCl}$ used to wash the column did not occur. Therefore, blood samples collected after $5 \mathrm{~mL}$ contained whole blood only as shown in Fig: 2.2 .

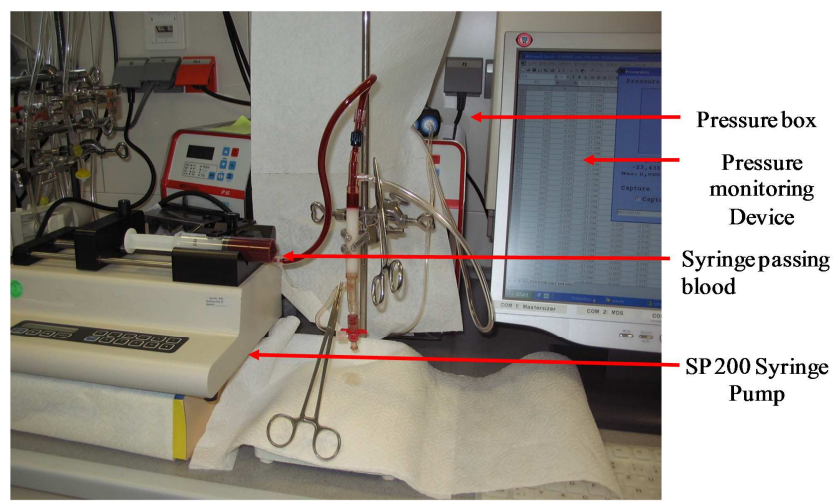

Figure 2.1. SP 200 syringe pump ready to pump blood through the cryogel column connected to the pressure box and the pressure monitor system. The metal clamps are used to close the tubes leading to the pressure box while loading blood sample. 

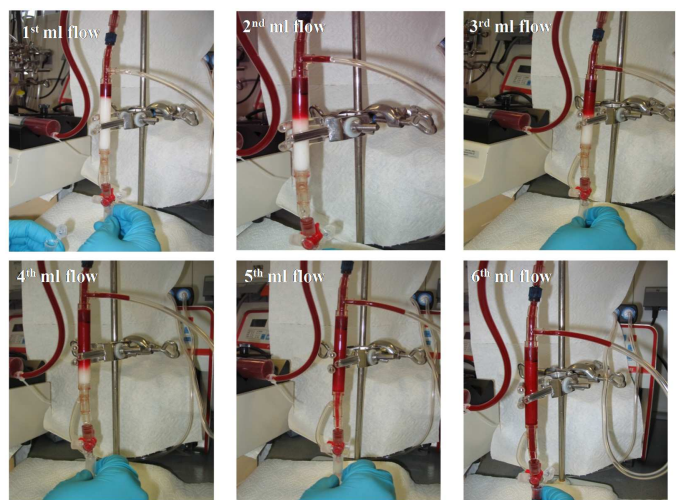

Figure 2.2. Flow of blood passing through the cryogel matrix at different times. No side flow leakage within the column was observed.

\subsection{Plasma Haemoglobin Determination}

Haemolytic potential of PHEMA cryogels has been evaluated by the haemolysis test. The haemolysis test is a qualitative characteristic that measures the free haemoglobin present in supernatant of the test sample; this measurement can be done photo-metrically.

To determine the effect of monolithic PHEMA cryogels on blood cells after transiting through the column, the following steps were taken.

i) The number of various blood cells in whole blood before passage through the column was estimated. ii) The pressure difference through the column during whole blood passage was measured. iii) Estimation of blood cells number eluted after transition through the column was done. iv) Evaluation of Red blood cells lysis was determined.

Freshly collected whole blood was passed through $8 \%$ PHEMA cryogel at a flow rate of $1 \mathrm{~mL} / \mathrm{min}$ with SP200 syringe pump connected to a pressure monitor device as shown in Fig. 2.1. Approximately $12 \mathrm{~mL}$ of blood was passed through the cryogel column and $1 \mathrm{~mL}$ fractions were collected into eppendorf and analysed for haemolysis. This experiment was repeated four different times.

$1 \mathrm{~mL}$ aliquots of blood from test samples were centrifuged at $1000 \mathrm{~g}$ for 10 minutes and the plasma was placed in another eppendorf tube. The absorbance of the plasma (300 $\mu \mathrm{L})$ was read and recorded at 3 wavelengths $(562,578$ and $598 \mathrm{~nm})$. The plasma haemoglobin concentration was calculated according to [30]. The total haemoglobin content (volume (gram) of haemoglobin in $\mathrm{dL}$ of whole blood) was measured with the Sysmex cell counter. Control samples (negative control $0.9 \% \mathrm{NaCl}$ in a $1: 1$ dilution with blood sample and positive control 1:1 dilution with deionized water) were incubated for 1 hour at room temperature. At the end of the incubation period, the samples were treated as described with test sample. Final plasma haemolysis was calculated as haemolytic index, this experiment was repeated four times for result comparison.

Calculation used for free plasma haemoglobin:

Free plasma Haemoglobin $(\mathrm{mg} / \mathrm{dL})=\left(\mathrm{A}_{578} \mathrm{X} 155\right)-\left(\mathrm{A}_{562}\right.$ $\mathrm{X} 86)-\left(\mathrm{A}_{598} \mathrm{X} 69\right)=$

To convert to Free plasma Haemoglobin $(\mathrm{g} / \mathrm{L})=$ Free plasma Haemoglobin $\left(\frac{m g / d L}{100}\right)$

Evaluation of results:

The haemolytic index is calculated according to Equation 2.1 .

\section{Haemolytic index $=$ \\ $\frac{\text { Free plasma haemoglobin released }\left(\frac{g}{L}\right)}{\text { Total plasma haemoglobin conc present }\left(\frac{g}{L}\right)} \times 100 \quad$ Equation 2.1}

\subsection{Coupling of IgG Ligand onto Monolithic Epoxy PHEMA Cryogels}

The epoxy PHEMA monolithic cryogels were treated as follows. The $4 \mathrm{~mL}$ cryogel column was connected to a pump and washed with $\sim 50 \mathrm{~mL}$ deionized water at a flow rate of $1 \mathrm{~mL} / \mathrm{min}$, and then with $0.1 \mathrm{M}$ sodium carbonate buffer $\mathrm{pH}$ $9.2(30 \mathrm{~mL})$. Ethylenediamine $(30 \mathrm{~mL}$ of $0.5 \mathrm{M}$ ethylenediamine in $0.1 \mathrm{M}$ sodium carbonate buffer $\mathrm{pH}$ 9.2) was applied to the column at flow rate of $1 \mathrm{~mL} / \mathrm{min}$ in recycle mode for 4hours. After washing with water until the $\mathrm{pH}$ was close to neutral, the column was washed with $0.1 \mathrm{M}$ sodium phosphate buffer $\mathrm{pH}$ 7.2. A solution of $5 \% \mathrm{v} / \mathrm{v}$, glutaraldehyde $(50 \mathrm{~mL})$ in $0.1 \mathrm{M}$ sodium phosphate buffer $\mathrm{pH}$ 7.2 , was applied to the column at flow rate of $1 \mathrm{~mL} / \mathrm{min}$ in recycle mode for 5 hours.

The derivatised cryogel matrices with functional aldehyde group were washed with $0.1 \mathrm{M}$ sodium phosphate $\mathrm{pH} 7.2$ buffer $\sim 50 \mathrm{~mL}$. The derivatised matrix with functional aldehyde groups was used for coupling of IgG. The IgG solution $(10.3 \mathrm{mg} / \mathrm{mL}$ of $\mathrm{IgG}$ dissolved in $20 \mathrm{~mL}$ of $0.1 \mathrm{M}$ sodium phosphate buffer $\mathrm{pH}$ 7.2), was recycled through the column at flow rate $1 \mathrm{~mL} / \mathrm{min}$ at $4^{\circ} \mathrm{C}$ for 24 hours. The monoliths were then washed with sodium phosphate buffer pH $7.2 \sim 50 \mathrm{~mL}$. Finally the freshly prepared $\mathrm{NaBH}_{4}$ solution, $0.05 \mathrm{M}$ sodium borohydride solution, in $0.1 \mathrm{M}$ sodium carbonate buffer, $\mathrm{pH} 9.2$ was applied to the cryogel column at a flow rate of $1 \mathrm{~mL} / \mathrm{min}$ for 3 hours in recycle mode to reduce Schiff's base formed between the protein ( $\operatorname{IgG}$ ) and the aldehyde-containing matrix. The monoliths were then washed with $0.1 \mathrm{M}$ sodium phosphate buffer $\mathrm{pH} 7.2 \sim 50 \mathrm{~mL}$ and stored at $4^{\circ} \mathrm{C}$ till further use.

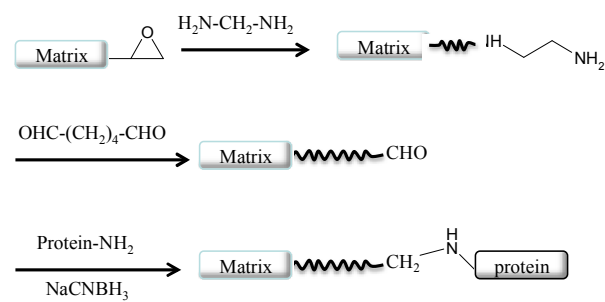

Figure 2.3. Schematic representation illustrating pathways to activate epoxy containing cryogel for antibody attachment.

\subsection{Affinity Binding of Human Serum Albumin to Cryogel Matrix with Immobilised Anti- human Albumin (Anti- HSA IgG) Ligands}

In order to evaluate the application of the separation strategy on another cell system, IgG cryogel matrix was used 
for capturing human serum albumin. Cryogel monoliths with immobilised anti-HSA IgG were produced as described in section 2.7. The HSA solution (prepared by dissolving $37 \mathrm{mg}$ of human serum albumin in $45 \mathrm{~mL}$ of $0.1 \mathrm{M}$ sodium phosphate buffers, $\mathrm{pH}$ 7.2) was recycled through the column at flow rate $1 \mathrm{~mL} / \mathrm{min}$ at $4{ }^{\circ} \mathrm{C}$ for 24 hours. The monoliths were then washed with $0.1 \mathrm{M}$ sodium phosphate buffers, $\mathrm{pH}$ $7.2 \sim 50 \mathrm{~mL}$ each. These monoliths were then stored at $4^{\circ} \mathrm{C}$ till further use in the wet state.

\subsection{Determination of Protein Content by Bicinchoninic Acid (BCA) Method}

The amount of protein content immobilised on epoxy PHEMA monolithic cryogel matrix was determined by the bicinchoninic acid method [31]. The BCA stock solution was freshly prepared by mixing bicinchoninic acid solution and copper (II) sulphate at a ratio of 50:1 (v/v) respectively. The cryogel matrix was dried in the oven at $60^{\circ} \mathrm{C}$ overnight, and was then ground finely into powder. A suitable amount of dried IgG cryogel were suspended in $1 \mathrm{~mL}$ of the BCA solution and the mixture was incubated at $37^{\circ} \mathrm{C}$ with thorough shaking for 30 minutes. The absorbance was measured at $562 \mathrm{~nm}$ both with and without centrifuging the samples. As the appropriate controls, epoxy PHEMA cryogel were used. For the standard curve, samples of diluted antihuman albumin solutions ( $\operatorname{IgG}$ ) were prepared by serial dilution of $4.675 \mathrm{mg} / \mathrm{mL} \mathrm{IgG}$ solution in $0.1 \mathrm{M}$ sodium phosphate buffers, $\mathrm{pH} 7.2$ to yield a calibration curve between $0.07 \mathrm{mg} / \mathrm{mL}$ to $1 \mathrm{mg} / \mathrm{mL}$. As a blank, PBS solution was used. The analysis of each sample was done in triplicate. UV absorbance was read against the blanks at $562 \mathrm{~nm}$ and an average value was recorded.

Thereafter, the amount of protein in the unknown sample was obtained from the standard curve. The protein based immobilisation yield was calculated as the percentage of the protein content of the cryogel immobilised with IgG to the respective amount of protein used for immobilisation.

\section{Results}

\subsection{Flow of Whole Blood through Cryogel Column}

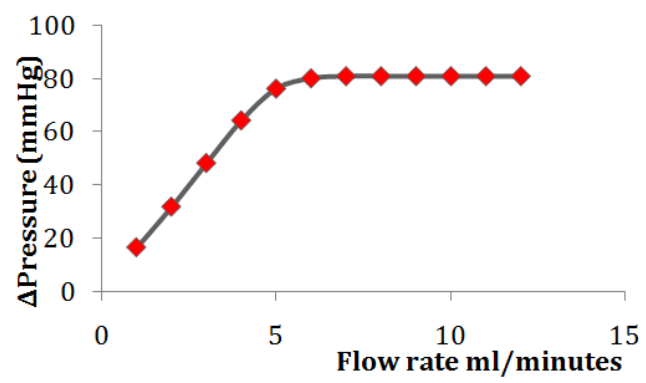

Figure 3.1. $\Delta$ Pressure against flow rate as pump passes blood through $8 \%$ PHEMA cryogel column at a speed of $1 \mathrm{~mL} / \mathrm{min}$.

Whole blood was passed through the column at a flow rate of $1 \mathrm{~mL} / \mathrm{min}$ and at approximately $6 \mathrm{~mL}$ or 6 minutes the column was filled with blood as shown in Fig 2.2, the maximum pressure of approximately $81 \mathrm{mmHg}$ was observed as shown in Fig.3.2. The gel matrix did not compress or reduce in size, which indicates that the cryogel matrix comprises macroporous interconnected pores, which allow the passage of various cells in the blood at a pressure of approximately $81 \mathrm{mmHg}$ at $1 \mathrm{~mL} / \mathrm{min}$ flow rate. These data suggest the column is mechanically stable and comprises macroporous interconnected pores.

\subsection{Blood Cell Count by Sysmex Cell Counter}

About $95 \%$ of the red blood cells were eluted at 6 minutes and after 9 minutes full recovery of RBC was observed

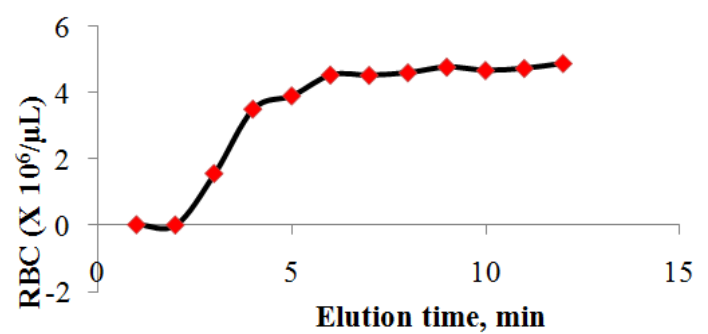

Figure 3.2. RBC counts after blood flow through the 8\% PHEMA cryogel column.

No haemolysis was observed in any samples eluted from the four $8 \%$ PHEMA cryogel columns as shown in Table 3.2 and 3.3, using the conversion haemolytic index in Table, 3.1. [32]. The results from Sysmex cell counter correlate with data from Blankey and Dinewoodie spectra method.

Table 3.1. Conversion table of haemolytic index.

\begin{tabular}{ll}
\hline Haemolytic index $(\%)$ & Haemolytic grade \\
\hline $0-2$ & Non haemolytic \\
$2-10$ & Slightly haemolytic \\
$10-20$ & Moderately haemolytic \\
$20-40$ & Markedly haemolytic \\
40 & Severely haemolytic \\
\hline
\end{tabular}

Table 3.2. Haemolysis results using Blankey and Dinewoodie spectra method.

\begin{tabular}{llll}
\hline Samples & $\begin{array}{l}\text { Haemoglobin } \\
\text { released } \\
\text { (g/L) }\end{array}$ & $\begin{array}{l}\text { Haemolytic } \\
\text { index (\%) }\end{array}$ & Haemolytic grade \\
\hline Negative control & 0.036 & 0.026 & Non haemolytic \\
Positive control & 3.6 & 2.6 & Slightly haemolytic \\
First column & 0.043 & 0.03 & Non haemolytic \\
Second column & 0.033 & 0.024 & Non haemolytic \\
Third column & 0.115 & 0.082 & Non haemolytic \\
Fourth column & 0.238 & 0.171 & Non haemolytic \\
\hline
\end{tabular}

Table 3.3. Haemolysis results using Sysmex cell counter.

\begin{tabular}{llll}
\hline Samples & $\begin{array}{l}\text { Haemoglobin } \\
\text { released } \\
(\mathbf{g} / \mathbf{L})\end{array}$ & $\begin{array}{l}\text { Haemolytic } \\
\text { index }(\%)\end{array}$ & Haemolytic grade \\
\hline Negative control & 1.28 & 0.92 & $\begin{array}{l}\text { Non haemolytic } \\
\text { Moderately } \\
\text { haemolytic }\end{array}$ \\
Positive control & 12.8 & 9.21 & Non haemolytic \\
First column & 1.07 & 0.76 & Non haemolytic \\
Second column & 1.23 & 0.88 & Non haemolytic \\
Third column & 1.04 & 0.75 & Non haemolytic \\
Fourth column & 1.29 & 0.93 & \\
\hline
\end{tabular}




\subsection{Coupling of Anti-human Albumin (IgG) Ligand onto Monolithic Epoxy PHEMA Cryogel}

Monolithic macroporous cryogels produced from epoxy PHEMA were macroporous polymeric materials with interconnected pore structure.

The quantity of $\operatorname{IgG}$ (protein content) immobilised on $8 \%$ w/v epoxy PHEMA was estimated by the standard BCA method. The results of proteins and protein based immobilisation yields are summarized in Table. 3.4. This result shows approximately $91 \%$ of $\mathrm{IgG}$ protein was immobilised on HEMA: AGE cryogels. However, the epoxy plain cryogels (cryogels with no surface derivatised with either ethylenediamine or glutaraldehyde, but incubated with protein) had no protein on the surface of the cryogel.

Table 3.4. Protein (IgG) contents on monolithic cryogels determined using bicinchoninic acid (BCA) method (Mean $\pm S D n=3$ ).

\begin{tabular}{lll}
\hline $\begin{array}{l}\text { Cryogel total monomer } \\
\text { concentration }\end{array}$ & $\begin{array}{l}\text { Protein content per } \\
\text { weight of monolith } \\
\text { (mg/g-monolith) }\end{array}$ & $\begin{array}{l}\text { Immobilisation } \\
\text { yield (\%) }\end{array}$ \\
\hline $8 \%$ w/v HEMA: AGE & $290 \pm 26.4$ & 91.5 \\
$8 \%$ w/v Plain HEMA: AGE & $10 \pm 1.5$ & 3.2 \\
\hline
\end{tabular}

\subsection{Affinity Binding of Human Albumin to Cryogel with Immobilised IgG}

Table 3.5 presents the binding of human serum albumin. Prior to affinity binding of the human serum albumin on the cryogel-protein surfaces, as a control, the human serum albumin was applied to $4 \mathrm{~mL}$ epoxy PHEMA cryogel matrix (without affinity ligand). The human serum albumin capture performed on such control surfaces showed minimum nonspecific binding $(<10 \%)$. About $82 \%$ of human serum albumin was retained on the monolithic IgG cryogel matrix.

Table 3.5. Total protein (anti-human albumin (IgG) plus human serum albumin) contents on monolithic cryogels determined using bicinchoninic acid (BCA) method (Mean $\pm S D n=3$ ).

\begin{tabular}{lll}
\hline $\begin{array}{l}\text { Cryogel total monomer } \\
\text { concentration }\end{array}$ & $\begin{array}{l}\text { Protein content per } \\
\text { weight of monolith } \\
\text { (mg/g -monolith) }\end{array}$ & $\begin{array}{l}\text { Immobilisation } \\
\text { yield (\%) }\end{array}$ \\
\hline $8 \%$ w/v HEMA: AGE & $556 \pm 25.8$ & 82 \\
$8 \%$ w/v Plain HEMA: AGE & $15 \pm 1.3$ & 2.2 \\
\hline
\end{tabular}

\section{Discussion}

In this study the haemolytic potential of poly (2hydroxyethyl methacrylate) PHEMA cryogels was analysed. The degree of haemolysis (Haemolytic Index) was determined by calculating the amount of free haemoglobin in the blood substrate supernatants after photometric detection at 562,578 and $598 \mathrm{~nm}$. The haemolytic index of the sample test was compared with that of the negative and positive control.

The data show that the haemolytic indices of the blood substrate supernatants of the negative control and the sample test were below $1 \%$ and therefore the material is classified as non-haemolytic.
A treatment of the blood substrate with deionised water (positive control) lead to a substantial increase in the haemolytic index (mean 5.90). According to the converting criteria the positive control has to be classified as slightly haemolytic.

The $100 \%$ elution of RBC without haemolysis after 12 minutes could indicate that the $8 \%$ PHEMA cryogel column has interconnected pores large enough for the passage of cells as big as 7-10 $\mu \mathrm{m}$ without any hindrances or entrapment.

The large pore size in the cryogel, in combination with the highly interconnected pore morphology and hydrophilic nature of pore walls formed from a cryogel, allow molecules and larger blood constituents such as cells of nano to micro meter size to pass unretained through the monolithic cryogel column in the absence of ionic or specific interactions between the ligands coupled to the cryogel. Steric hindrance between immobilised ligand (antibody IgG) and large target molecules can occur during interaction with immobilised protein [33].

To overcome this problem, the $\operatorname{IgG}$ was coupled to the epoxy-containing macroporous cryogel matrix through a spacer arm. The two-step derivatisation includes reaction with ethylenediamine, followed by the reaction with glutaraldehyde giving a spacer arm of seven carbon atoms. Further improvement in the binding efficiency could be expected when using even longer extension arms, but this may also increase the non-specific binding in some cases. The results show at least $90 \%$ of the amount of IgG used was immobilised onto the cryogel surface

The absence of immobilisation on epoxy plain cryogels (cryogels with no surface derivatised with either ethylenediamine or glutaraldehyde, but incubated with protein) explains that protein cannot be adsorbed or bound easily onto the cryogel matrix because the cryogel possesses hydrophilic features with low non-specific adsorption of protein and also adsorption is difficult without a spacer arm.

Non-specific absorption of proteins to the surface occurs naturally, whenever protein has contact with any surface. However, bio-specific affinity reaction occurs with the use of biological compounds such as immunoglobulin-binding proteins, enzymes, lectins and carbohydrates as ligands. The analyte is captured in a highly selective manner via molecular recognition by the ligand present on the column. The results could suggest that direct immobilisation of antibodies on the cryogel material and applying for affinity captures a lower binding when compared with about 95\% specific cell binding on protein A monolithic cryogel matrix as reported in [34] and about $94 \%$ of specific B-cells on protein A column was reported in [24]. This may be because of the poor orientation and also some inactivation of the antibody molecules when coupled directly to the matrix. For better orientation of the immobilised antibody molecules, one of the most common methods utilized is the immobilisation of antibodies at Fc region through the use of protein A [35].

Cryogel is a highly porous polymeric material, which possesses large pore size and hence results in a small area (per unit of column volume) available for ligand coupling 
and hence in low binding capacity for protein binding [36], as compared with traditional packed-bed adsorbents. However, low ligand density seems to be beneficial for chromatographic separation of cells having multiple interactions with the surface. High ligand densities result in multipoint cell-matrix interactions and hence problems with the recovery of bound cells [37]. The potential of polymeric cryogels in bioseparation has been discussed earlier in a review [38, 39]. This present work demonstrates that cryogels have promising potential, as separation media when dealing with macromolecules, thus might be a suitable filter matrix in extracorporeal apheresis device.

\section{Conclusions}

It has been proved in this study that under the indicated conditions poly (2-hydroxyethyl methacrylate) PHEMA cryogels did not contain any leachable substances with haemolytic activity. The haemocompatibility finding shows approximately $100 \%$ of Red blood cells was eluted after passage through the column, with no haemolysis observed in the eluent. The results from Sysmex cell counter correlate with data from Blankey and Dinewoodie spectra method, therefore PHEMA cryogel could be classified as nonhaemolytic. Immobilisation of anti-human albumin ( $\mathrm{IgG}$ ) and affinity binding of human serum albumin to the $\mathrm{IgG}$ immobilised matrix demonstrate the bio-affinity potential of antibody used as ligands for protein purification. Thus, monolithic cryogels have promising potential as a matrix for blood purification and can be a suitable matrix for extracorporeal apheresis medical devices.

\section{Acknowledgement}

The authors are grateful to Prof Dieter Falkenhagen, Dr Viktoria Weber and Dr Anita Schildberger of Department for Clinical Medicine and Biotechnology, Centre for Biomedical Technology Krems Donau University (Austria) for their help with haemolytic potential test. Prof Bo Mattiasson and Dr Harald Kirsebom of Department of Biotechnology, Centre for Chemistry and Chemical Engineering, Lund University (Sweden) for guidance with functionalisation of the matrix.

This work was financially supported by European Commission Marie Curie Actions FP7 IAPP MONACO EXTRA project (218242), Erasmus grant and University of Brighton PhD studentship.

\section{References}

[1] Ratner, B.D., et al., Biomaterials Science - An Introduction to Materials in Medicine, ed. n. Edition. 2004: Elsevier.

[2] Ratner, B.D., et al., Introduction - Biomaterials Science: An Evolving, Multidisciplinary Endeavor, in Biomaterials Science (Third Edition), B.D.R.S.H.J.S.E. Lemons, Editor. 2013, Academic Press. p. xxv-xxxix.
[3] Ueki, Y., et al., Evaluation of filtration leucocytapheresis for use in the treatment of patients with rheumatoid arthritis. Rheumatology, 2000. 39(2): p. 165-171.

[4] Hidaka, T., et al., Filtration leukocytapheresis therapy in rheumatoid arthritis: A randomized, double-blind, placebocontrolled trial. Arthritis \& Rheumatism, 1999. 42(3): p. 431437.

[5] Morihiro, O., et al., Granulocytapheresis in the treatment of patients with rheumatoid arthritis. Journal of Artificial Organs, 1997. 21(9): p. 989-994.

[6] Sawada, K., et al., Leukocytapheresis therapy, performed with leukocyte removal filter, for inflammatory bowel disease. Journal of Gastroenterology, 1995. 30(3): p. 322-329.

[7] Rembacken, B.J., et al., Granulocyte apheresis in inflammatory bowel disease: Possible mechanisms of effect. Therapeutic Apheresis and Dialysis, 1998. 2(2): p. 93-96.

[8] Shimoyama, T., et al., Safety and efficacy of granulocyte and monocyte adsorption apheresis in patients with active ulcerative colitis: A multicenter study. Journal of Clinical Apheresis, 2001. 16(1): p. 1-9.

[9] Bosch, T., et al., Direct adsorption of low-density lipoprotein and lipoprotein(a) from whole blood: Results of the first clinical long-term multicenter study using DALI apheresis. Journal of Clinical Apheresis, 2002. 17(4): p. 161-169.

[10] Bosch, T. and T. Wendler, Efficacy and safety of DALI-LDLapheresis in two patients treated with the angiotensin IIreceptor 1 antagonist losartan. Therapeutic Apheresis and Dialysis, 2004. 8(4): p. 269-274.

[11] Shibata, H., T. Kuriyama, and N. Yamawaki, Cellsorba. Therapeutic Apheresis and Dialysis, 2003. 7(1): p. 44-47.

[12] Saniabadi, A.R., et al., Adacolumn, an adsorptive carrier based granulocyte and monocyte apheresis device for the treatment of inflammatory and refractory diseases associated with leukocytes. Therapeutic Apheresis and Dialysis, 2003. 7(1): p. 48-59.

[13] Agishi, T., Birth of the concept and the development of extracorporeal immunomodulation. Therapeutic Apheresis, 2002. 6(4): p. 312-316.

[14] Archontakis, S., P. Alison, and B. Mahmoud, Low-density lipoprotein-apheresis: an update. The British Journal of Cardiology, 2008. 15(2): p. 83-85.

[15] Bosch, T., et al., DALI apheresis in hyperlipidemic patients: biocompatibility, efficacy, and selectivity of direct adsorption of lipoproteins from whole blood. Artificial Organs, 2000. 24(2): p. 81-90.

[16] Tetala, K.K.R. and T.A. van Beek, Bioaffinity chromatography on monolithic supports. Journal of Separation Science, 2010. 33(3): p. 422-438.

[17] Svec, F. and J.M.J. Frechet, New designs of macroporous polymers and supports: from separation to biocatalysis. Science, 1996. 273(5272): p. 205-211.

[18] Akande Wuraola, et al., Poly (2-Hydroxyethyl Methacrylate) Macroporous Cryogel for Extracorporeal Medical Devices. International Journal of Biomedical Materials Research, 2015. 3(4): p. 46-55. 
[19] Dainiak, M.B., I.Y. Galaev, and B. Mattiasson, Affinity cryogel monoliths for screening for optimal separation conditions and chromatographic separation of cells. Journal of Chromatography A, 2006. 1123(2): p. 145-150.

[20] Gun'ko, V.M., I.N. Savina, and S.V. Mikhalovsky, Cryogels: morphological, structural and adsorption characterisation. Adv Colloid Interface Sci, 2013. 187-188: p. 1-46.

[21] Dainiak, M.B., et al., Detachment of affinity-captured bioparticles by elastic deformation of a macroporous hydrogel. Proceedings of the National Academy of Sciences, 2006. 103(4): p. 849-854.

[22] Savina, I.N., et al., Porous structure and water state in crosslinked polymer and protein cryo-hydrogels. Soft Matter, 2011. 7(9): p. 4276-4283.

[23] Onodera, H., et al., Development of a device for selective removal of CD4+ T cells. Therapeutic Apheresis and Dialysis, 2003. 7(3): p. 329-333.

[24] Kumar, A., et al., Affinity fractionation of lymphocytes using a monolithic cryogel. Journal of Immunological Methods, 2003. 283(1-2): p. 185-194.

[25] Ingavle, G.C., et al., Affinity binding of antibodies to supermacroporous cryogel adsorbents with immobilized protein A for removal of anthrax toxin protective antigen. Biomaterials, 2015. 50: p. 140-53.

[26] Kempe, D.S., et al., Stimulation of erythrocyte phosphatidylserine exposure by lead ions. American Journal of Physiology - Cell Physiology, 2005. 288(2): p. C396-C402.

[27] Streller, U., et al., Design and evaluation of novel blood incubation systems for in vitro hemocompatibility assessment of planar solid surfaces. Journal of Biomedical Materials Research Part B: Applied Biomaterials, 2003. 66B(1): p. 379390.

[28] Henkelman, S., et al., Standardization of incubation conditions for hemolysis testing of biomaterials. Materials Science and Engineering: C, 2009. 29(5): p. 1650-1654.

[29] Dillingham, E.O., et al., Biological evaluation of polymers I. Poly(methyl methacylate). Journal of Biomedical Materials Research, 1975. 9(6): p. 569-596.
[30] Blakney, G. B, and A. Dinwoodie, J., A spectrophotometric scanning technique for the rapid determination of plasma hemoglobin. Journal of Clinical Biochemistry, 1975. 8(2): p. 96-102.

[31] Smith, P.K., et al., Measurement of protein using bicinchoninic acid. Analytical Biochemistry, 1985. 150(1): p. 76-85.

[32] Kay, L.A., Essentials of haemostasis and thrombosis, in Essentials of haemostasis and thrombosis. 1988, Churchill Livingstone, Edinburgh. p. 290.

[33] Luo, Q., et al., High-performance affinity chromatography with immobilization of protein A and L-histidine on molded monolith. Biotechnology and Bioengineering, 2002. 80(5): p. 481-489.

[34] Kumar, A., et al., Affinity binding of cells to cryogel adsorbents with immobilized specific ligands: effect of ligand coupling and matrix architecture. Journal of Molecular Recognition, 2005. 18(1): p. 84-93.

[35] Anderson, G.P., et al., Effectiveness of protein A for antibody immobilization for a fiber optic biosensor. Biosensors and Bioelectronics, 1997. 12(4): p. 329-336.

[36] Arvidsson, P., et al., Direct chromatographic capture of enzyme from crude homogenate using immobilized metal affinity chromatography on a continuous supermacroporous adsorbent. Journal of Chromatography A, 2003. 986(2): p. 275-90.

[37] Ujam, L.B., et al., Isolation of monocytes from human peripheral blood using immuno-affinity expanded-bed adsorption. Biotechnology and Bioengineering, 2003. 83(5): p. 554-566.

[38] Lozinsky, V., et al., The potential of polymeric cryogels in bioseparation. Bioseparation, 2001. 10(4): p. 163-188.

[39] Hajizadeh, S., and B. Mattiasson, Cryogels with Affinity Ligands as Tools in Protein Purification, in Affinity Chromatography, S. Reichelt, Editor. 2015, Springer New York. p. 183-200. 